\title{
Index/Table des Matières Volume XX, 1984
}

\section{Authors/Auteurs}

ANSELMENT, Raymond A. Alexander Brome and the Search for the "Safe Estate," 39.

BAILLIE, William M. (review) Dewey Ganzel, Fortune and Men's Eyes: The Career of John Payne Collier, 146.

BAKER, J. Wayne. (review) James Martin Estes, Christian Magistrate and State Church: The Reforming Career of Johannes Brenz, 136.

BOENIG, Robert. Listening to Herbert's Lute, 298.

BERK, Philip R. (review) Lucien Febvre, The Problem of Unbelief in the Sixteenth Century: The Religion of Rabelais, trans. Beatrice Gottlieb; Le Disciple de Pantagruel (Les Navigations de Panurge), eds. Guy Demerson et Christiane LauvergnatGagniere, 123.

BERTHIAUME, Andrè. Pratique de la citation dans les Essais de Montaigne, 91.

BOND, Ronald B. Vying with Vision: An Aspect of Envy in The Faerie Queene, 30.

BORNSTEIN, Daniel. (review) Ronald F.E. Weissman, Ritual Brotherhood in Renaissance Florence, 151.

BULLOCK, Alan. (review) Torquato Tasso, Creation of the World, trans. Joseph Tusiani, annot. Gaetano Cipolla, 128.

CAMERON, Angus. (review) Cart T. Berkout and Milton McGatch, eds., AngloSaxon Scholarship: the first three centuries, 226.
CARNES, Pack. The Fable in Service to the Reformation, 176.

CARRITHERS, Gale H., Jr. (review) John R. Roberts, John Donne: An Annotated Bibliography of Modern Criticism, 1968-1978, 149.

CARTIER, Ginette. Musique et pouvoir à l'aube de la Renaissance: le metier de la musicien à la cour des Grand Ducs Valois de Bourgogne, 157.

D'AMICO, Jack. The Virtue of Ruin in Machiavelli's Florentine Histories, 202.

GINSBERG, Ellen S. (review) Victor Brodeau, Poésies, ed. Hilary M. Tomlinson, 121.

HALEWOOD, William H. (review) George Herbert, The Country Parson, ed. John N. Wall Jr., 67

HARVEY, Elizabeth D. (review) Clark Hulse, Metamorphic Verse: The Elizabethan Minor Epic, 64.

HILLMAN, Richard. (review) Ira Clark, Christ Revealed: The History of the Neotypological Lyric in the English Renaissance, 132.

JEAY, Madeleine. (compte rendu) Elisabeth Badinter, L'amour en plus. Histoire de l'amour maternal, XVIIe-XVIIIe siècle, 125.

KENNEDY, George A. (review) The Book of the Honeycomb's Flow by Juda Messer Leon, ed. and trans. Isaac Rabinowitz, 154.

KOHL, Benjamin G. (review) Richard A. Goldthwaite, The Building of Renaissance Florence, An Economic and Social History, 57. 
LAFORTUNE-MARTEL, Agatha. (compte rendu) Mireille Laget, Naissances. L'accouchement avant l'âge de la clinique, 134.

LOVE, Ronald S. Contemporary and Near-Contemporary Opinion of Louis XII, "Père de peuple," 235.

LOW, Anthony. (review) Ronald G. Shafer ed., Ringing the Bell Backward: The Proceedings of the First International Milton Symposium, 232.

LUKES, Timothy J. To Bamboozle with Goodness: the Political Advantages of Christianity in the Thought of Machivelli, 266.

MARC'HADOUR, Germain. (compte rendu) Alistair Fox, Thomas More: Hisry and Providence, 138.

MARGETTS, Michele. Erasmus' Colloquia: Dramatic Elements Real and Metaphorical, 1.

McGEE, C.E. (review) Robert Langham, A Letter, ed. R.J.P. Kuin, 228.

MOISAN, Jean-Claude. Le Jeu des simulacres ... ou la rhétorique consciente: Du Bellay-Ronsard, 19.

OWENS, J.B. (review) William A. Christian Jr., Apparitions in Late Medieval and Renaissance Spain and Local Religion in Sixteenth-Century Spain, 73.

PEARL, J.L. The Role of Personal Correspondence in the Exchange of Scientific Information in Early Modern France, 106.

PIEPHO, Lee. Versions by Thomas, Lord Fairfax of Some Poems by Mantuan and Other Italian Neo-Latin Writers, 114.

REYNOLDS, Anne. (review) Stillman Drake, Galileo at Work: His Scientific Biography, 56.

RICHTER, Bodo L.O. (review) Malcolm Smith, Montaigne and the Roman Censors, 62.

SHAMI, Jeanne M. (review) Troy D. Reeves, An Index to the Sermons of John Donne, 59.
SIL, Narasingha Prosad. Sir Anthony Denny: A Tudor Servant in Office, 190.

SIMARD, Yvon. (compte rendu) Moreana, vol. XVIII, no. 69, 1981, 69.

STAYER, James M. (review) Carl C. Christensen, Art and the Reformation in Germany, 54.

SUTTO, Claude. Tradition et innovation, Réalisme et utopie: L'idee gallicane à la fin du XVIe et au debut de XVIIe siècles, 278.

TRESIDDER, Warren. (review) Clifford M. Brown, Isabella d'Este and Lorenzo da Pavia, Documents for the History of Art and Culture in Renaissance Mantua, 144.

UNGERER, Gustav. The Viol da Gamba as a Sexual Metaphor in Elizabethan Music and Literature, 79.

WRIGHT, Elizabeth C. (review) The Paradise of Women: Writings by Englishwomen of the Renaissance, ed. Betty Travisky, 52.

\section{Books Reviewed / Comptes Rendus}

BADINTER, Elisabeth. L'amour en plus. Histoire de l'amour maternal, SVIIeXVIIIe siècle, 125.

BERKOUT, Carl T., and Milton McGatch, ed.Anglo-Saxon Scholarship: the first three centuries, 226.

BROWN, Clifford M. Isabella d'Este and Lorenzo de Pavia, Documents for the History of Art and Culture in Renaissance Mantua, 144.

CHRISTENSEN, Carl C. Art and the Reformation in Germany, 52.

CHRISTIAN, William A. Apparitions in Late Medieval and Renaissance Spain and Local Religion in Sixteenth-Century Spain, 73.

CLARK, Ira. Christ Revealed: The History of the Neotypological Lyric, 132.

Collected Works of Erasmus, Volume 6, The Correspondence of Erasmus: Letters 842 to 992 (1518 to 1519), XXX. 
DEMERSON, Guy and Christiane Lauvergnat-Gagniere, eds. Le Disciple de Patagruel (Les Navigations de Panurge), 123.

DRAKE, Stillman. Galileo at Work: His Scientific Biography, 56.

ESTES, James Martin. Christian Magistrate and State Church: The Reforming Career of Johannes Brenz, 136.

FOX, Alistair. Thomas More: History and Providence, 138.

GANZEL, Dewey. Fortune and Men's Eyes: The Career of John Payne Collier, 146.

GOLDTHWAITE, Richard A. The Building of Renaissance Florence: An Economic and Social History, 57.

HULSE, Clark. Metamorphic Verse: The Elizabethan Minor Epic, 64.

KUIN, R.J.P., ed. Robert Langham, $A$ Letter, 228.

LAGET, Mireille. Naissances. L'accouchement avant l'âge de la clinique, 134.

LAUVERGNAT-GAGNIERE, Christiane and Guy Demerson, eds. Le Disciple de Pantagruel (Les Navigations de Panurge), 123.

LEFVRE, Lucien. The Problem of Unbelief in the Sixteenth Century: The Religion of Rabelais, 123.

McGATCH, Milton, and Carl T. Berkout, eds. Anglo-Saxon Scholarship: the first three centuries, 226.

Moreana, Vol. XVIII, no. 69, 1981, 69.

RABINOWITZ, Isaac, ed. and trans. The Book of the Honeycomb's Flow by Juda Messer Leon, 154.

REEVES, Troy D. An Index to the Sermons of John Donne, 59.

ROBERTS, John R. John Donne: An Annotated Bibliography of Modern Criticism, 1968-1978, 149.
SHAFER, Ronald G., ed. Ringing the Bell Backward: The Proceedings of the First International Milton Symposium, 232.

SMITH, Malcolm. Montaigne and the Roman Censors, 62.

TOMLINSON, Hilary M., ed. Victor Brodeau, Poésies, 121.

TRAVISKY, Betty, ed. The Paradise of Women: Writings by Englishwomen of the Renaissance, 52.

TUSIANI, Joseph, trans. Torquato Tasso, Creation of the World, 128.

WALL, John N., Jr., ed. George Herbert, The Country Parson, 67.

WEISSMAN, Ronald F.E. Ritual Brotherhood in Renaissance Florence, 151. 